\title{
Furfural production from the peels of ripe pawpaw (carica papaya I.) and pineapple (ananas comosus) fruits by acid catalyzed hydrolysis
}

\author{
D. Wankasi , T. J. Tarawou and J. A. Yabefa \\ Department of Chemical Sciences, Faculty of Science, Niger Delta University, Wilberforce \\ Island, P. M. B. 071, Yenagoa, Bayelsa State, Nigeria
}

\begin{abstract}
The peels of ripe carica papaya $L$ and ananas comosus fruits were hydrolyzed with $4.5 \mathrm{~m}$ Hydrochloric acid solution. The hydroxylates were tested for furfural using volumetric, uv/visible and IR spectroscopic methods in addition to other physicochemical parameters. The uv/visible and IR spectrophotometric scans confirm the presence of furfural. The results show high yield of furfural.
\end{abstract}

Keywords: Furfural, Production, Pawpaw, Pineapple.

\section{INTRODUCTION}

Agricultural wastes or by-products remain the most convenient source of renewable raw materials or feedstock for the chemical industry.

The importance of furfural and its derivatives has increased due to its very wide applications and this has made it imperative for the search for cheap, renewable and always available feedstock for the production of furfural.

The possibility of using agricultural wastes or byproducts for the production of furfural has been recognized for many years and over the last 60 years a more considerable fund of information has been built up. These include the production of furfural from corn-corbs, rice hulls, bagasse (saad et al, 1978), palm fruit fibre (odozi et al 1985), Garbage (Win, 2005).

The actual chemistry involved in the production of furfural from agricultural wastes as a source of hemicellulose or pentosan is by acid catalysed hydrolysis.

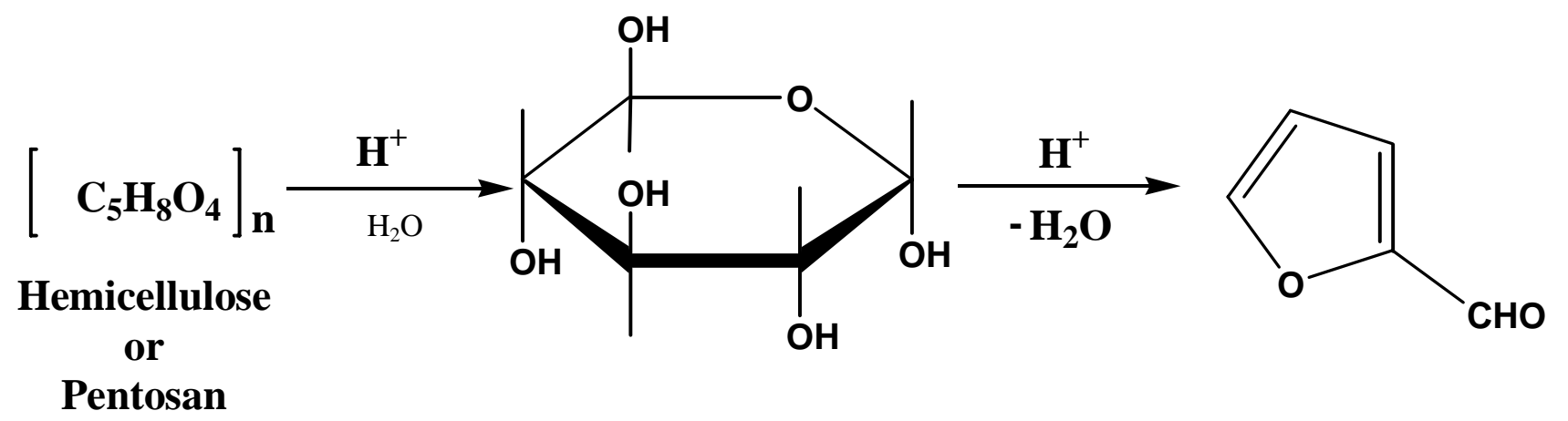

Pentosan is one of the important fibre components of the non-starch polysaccharide called himecellulose. Hemicellulose can be any of several heteropolymers present in almost all cell walls.

Carica papaya $L$ belongs to the family of CaricaceaeBurnet. It is a dicot genu of about 50 species of tropical American (Mexico and Costa Rica) origin. The genus is represented in Nigeria by one species called carica papaya L. (Nyananyo, 2006). Other species of less importance in the genus though may not be represented in Nigeria are C. candamercensis hook. F. the wild papaya of south and central American origin.

Ananas comosus is a tropical plant and fruit (multiple), native to Brazil and Paraguay. It is found in West Africa, particularly in Nigeria (Nyananyo, 2006) and belongs to the Plantae Kingdom and Bromeliaere family. It contains sugars, fat, protein, vitamins, minerals and a proteolytic enzyme bromelain which digests food by breaking down protein. 


\section{MATERIALS AND METHODS}

Sample collection and preparation: Ripe carica papaya $L$ and ananas comosus were obtained from Amassoma near Yenagoa in Bayelsa State of Nigeria. The peels of the fruit were separated from the mesocarp and chopped to reduce the sizes. The peels were then oven dried at $60^{\circ} \mathrm{c}$ for 48 hours and ground to 500um mesh sizes.

Furfural production by acid hydrolysis : 20 grams of the 500um mesh sizes of the peels of ripe carica papaya $L$ and ananas comosus were weighed into a round bottom flask and refluxed with $500 \mathrm{ml}$ of 4.5 $\mathrm{HCl}$ solution for one hour. The hydroxylate was cooled, then filtered and stored in brown reagent bottles for further experimentation.

Density of hydroxylates: The empty density bottle was weighed and recorded. The density bottle was then filled with the hydroxylates and the weight recorded. The difference in weight was taken and the density computed.

Boiling point determination: $70 \mathrm{ml}$ of hydroxylates was measured into a clean $100 \mathrm{ml}$ beaker and a thermometer with a capillary tube tied together was inserted. The beaker with its content were then heated using a hot plate until the first bubble was observed. The temperature at this point was read and recorded.
pH of hydroxylates: the $\mathrm{pH}$ meter was standardized with buffer solutions and then $25 \mathrm{ml}$ of each sample hydroxylate was measured into a beaker. The $\mathrm{pH}$ values were read and recorded when the meter readings were stable.

Furfural estimates in hydioxylates: $25 \mathrm{ml}$ of each hydroxylate was measured into a conical flask and $20 \mathrm{ml}$ of $0.05 \mathrm{M}$ potassium bromate/bromide $\left(\mathrm{KBrO}_{3} / \mathrm{BKr}\right)$ solution added and allowed to stand for five minutes. $10 \mathrm{ml}$ of $5 \%(0.05 \mathrm{M})$ potassium iodine (KI) was then added and the liberated iodine titrated with a standard $0.1 \mathrm{M}$ sodium thiosulphate $\left(\mathrm{Na}_{2} \mathrm{~S}_{2} \mathrm{O}_{3}\right.$. $5 \mathrm{H}_{2} \mathrm{O}$ ) solution. Then the titre values (volumes of the $\mathrm{Na}_{2} \mathrm{~S}_{2} \mathrm{O}_{3} \mathrm{H}_{2} \mathrm{O}$ ) were recorded. $A$ blank experiment was conducted under the same conditions.

UV/Visible Spectrophotometric Scanning of Hydroxylates: A Jenway 6505 single beam scanning spectrophotometer was used to scan the products of the reflux reaction (hydioxylate). The equipment was set to scan from $200-700 \mathrm{~mm}$ at a scan speed of $5 \mathrm{~nm}$ per minute.

IR spectroscopic scanning of hydiozylates: A drop of the neat sample was placed between two polished flat sodium chloride plates (cells) which were squeezed together and mounted in the FTIR SPECTROPHOTOMETER (model: IR PRESTIGE 21) SHIMADU CORPORATION, SNO: A21004200709) and scanned.

\section{RESULTS AND DISCUSSION}

Table 1 Physicochemical properties and percent yield of hydroxylates

\begin{tabular}{|l|c|c|}
\hline \multirow{2}{*}{\multicolumn{1}{|c|}{ Test }} & \multicolumn{2}{|c|}{ Agricultutal wastes } \\
\cline { 2 - 3 } \multicolumn{1}{c|}{$\mathrm{pH}$} & Carica Papaya L Peels & Ananas comosus peels \\
\hline Boiling point $\left({ }^{\circ} \mathrm{C}\right)$ & 5.72 & 5.72 \\
\hline Density $(\mathrm{g} / \mathrm{ml})$ & 161.0 & 160.0 \\
\hline Colour & 1.16 & 1.16 \\
\hline \% yield & Light - brown & Brown \\
\hline
\end{tabular}

Table 1 gives the densities of the hydroxylates as $1.16 \mathrm{~g} / \mathrm{ml}$ for both the carica papaya $\mathrm{L}$ and ananas comosus peels. These values are within the $1.16 \mathrm{~g} / \mathrm{ml}$ for furfural. This shows that furfural was produced during the acid hydrolysis. The boiling points as indicated in table $\mathrm{I}$ are $161^{\circ} \mathrm{C}$ and $160^{\circ} \mathrm{C}$ for carica papaya $\mathrm{L}$ and ananas comosus peels respectively. These values are within the $161.7^{\circ} \mathrm{C}$ for furfural and further confirms the conversion of these agricultural wastes to furfural.

The $\mathrm{pH}$ values of 5.72 for both carica papaya $L$ and ananas comosus peels hydroxylates are acidic. Table I also gives the percent yield of furfural to be 21.95 and 20.69 for carica papaya $L$ and ananas comosus peels respectively. 
Am. J. Food. Nutr, 2011, 1(3): 136-140

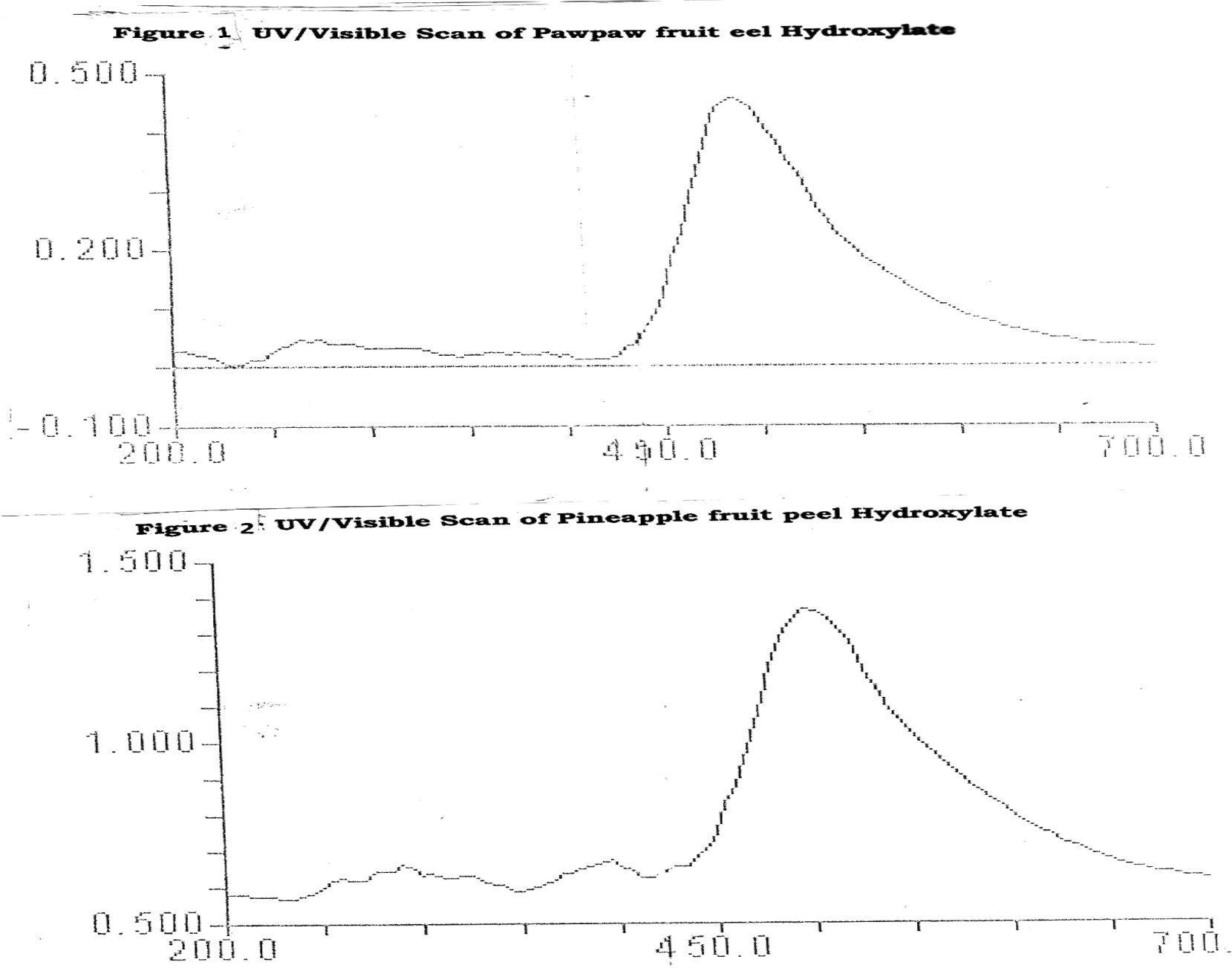

ketones give a weak absorption band in the ultraviolet region between $270-300 \mathrm{~nm}$. This band is shifted to longer wavelengths (300 - 350nm) when the carbonyl group is conjugated with a double bond (Solomon, 1978). As the degree of conjugation increases, the absorption will shift to longer wavelength. Generally, each additional double bond increases or gives use to longer wavelength. Each additional conjugated double bond increases the wavelength of absorption band for about 300nm (Kamala and Ogbome 2008).
Examination of the resulting spectra as shown in figures 1 and 2 revealed broad absorption bands in the regions between $350-500 \mathrm{~nm}$ for the two hydroxylates of carica papaya $L$ and ananas comosus peels. This significant absorption bands indicate the presence of conjugated unsaturated bonds. This also confirms the presence of furfural as the broad bands may be due to the conjugation in the furfural. 
Am. J. Food. Nutr, 2011, 1(3): 136-140

Figure 3 . Infrared Scan of Pawpaw Fruit Peel Hydroxylate

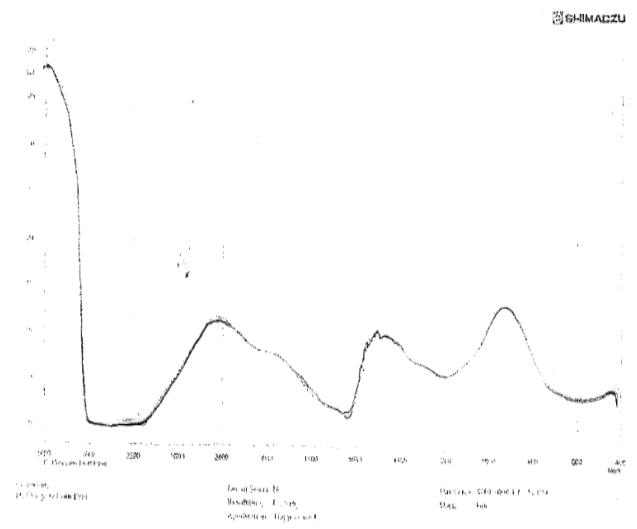

Figure $4:$ Infrared Scan of Pineapple Fruit Peel Hydroxylate

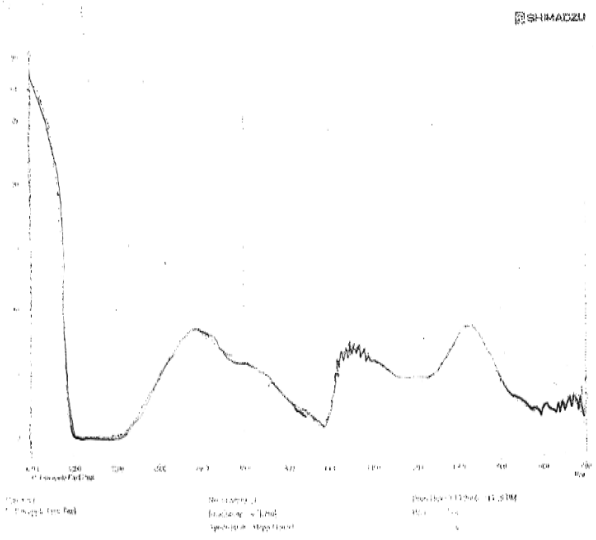


Carbonyl groups pf aldehydes and ketones give rise to very strong $\mathrm{C}=\mathrm{O}$ stretching bands in the 1665 $1780 \mathrm{~cm}^{-1}$ region of the infrared spectrum. The exact location of the peak depends on the structure of the aldehydes or ketone. For example R - CHO (1729 $\left.1740 \mathrm{~cm}^{-1}\right), \mathrm{Ar}-\mathrm{CHO}\left(1695-1715 \mathrm{~cm}^{-1}\right)$. The $\mathrm{CHO}$ group of aldehydes also gives two weak bands in the $2700-2775 \mathrm{~cm}^{-1}$ and $2820-2900 \mathrm{~cm}^{-1}$ regions of the infrared spectrum (Solomon,1978). Figures 3 and 4 are the infrared spectra of the carica papaya $L$ and ananas comosus peels hydroxylates respectively. The spectra show sharp peaks between 1650 $1700 \mathrm{~cm}^{-1}$ for the two hydroxylates which indicate the presence of aldehydes. This further confirms the production of furfural from the peels of carica papaya $\mathrm{L}$ and ananas comosus by the acid catalyzed hydrolysis.

\section{CONCLUSION}

This study revealed a good yield of the furfural from the peels of pawpaw (carica papaya L) and Pineapple (ananas comosus), which have been confirmed by the various tests including the uv/visible and infrared spectrophotometric scans. Based on these findings, peels of carica papaya $L$ and ananas comosus are good sources of renewable raw materials for the production of furfural.

\section{REFERENCES}

Kamalu O. I. C and Ogbome P. (2008): Extraction and characterization of Tiger Nut Oil J. Chem. Soc. Nigeria, vol. 33, No. 1, Pp $79-87$

Nyananyo, B. L. (2006): Plants from the Niger Delta. Onyoma Research Pub. Pp. $24-303$.

Odozi T. O., Akaranta O., Ogban I. U. (1985) Development of Wood Varnishes from Palm Fruit Fibre Hydroxylate (Eliesis Gelineesis) and Red Onion skin (Allium Cepa) Tannin Extract. Jocca 4: $94-97$

Saad S. M. Naser A. M., El - Zi, Abel - Moged (1978) 2 Furfuraldehyde (Furfural) formation from Local ByProducts and its utilization in the field of surface coatings. JOCCA 61: $41-48$.

Solomon T. W. G. (1978). Organic Chemistry. John Whiley and Sons - New York. Chichelar. Brisbane Toronto

Win T. D. (2005) Furfural - Gold from Garbage AUJT. 8 (4): $185-190$ 